\title{
Structural and functional changes of cardiovascular system in children with asthma
}

\author{
0. V. Herasymova, T. L. Protsiuk, L. O. Protsiuk, L. D. Kotsur
}

National Pirogov Memorial Medical University, Vinnytsia, Ukraine

Key words:

asthma,

cardiovascular

system, children.

Zaporozhye

medical journal

2018; 20 (5), 646-650

Dol:

10.14739/2310-1210

2018.5.141510

E-mail:

rossata@ukr.net
Objective. To study the cardiovascular system status in schoolchildren depending on the level of bronchial asthma control.

Materials and methods. The study enrolled 189 children with persistent BA aged 6-17 years and 30 gender- and age-matched apparently healthy individuals who made up a control group. In addition to clinical examinations assessment electrocardiogram (ECG) monitoring results and markers of myocardial damage (total creatine phosphokinase and lactic dehydrogenase, isoenzymes CPK-MB and $\mathrm{LDH}_{1}$ ) as well as electrolytes ( $\mathrm{K}^{+}$in serum and erythrocytes) were studied to assess the cardiovascular system status in children with various levels of $\mathrm{BA}$ control.

Results. Rhythm disturbances in the form of sinus tachycardia was detected in $30.6 \%$ of children with UC BA, and it was significantly more frequent compared to the children with $C B A-8.05 \%(P<0.01)$ and the control group $-6.06 \%(P<0.001)$. Bradycardia occurred significantly more often in those with uncontrolled BA (19.3\%) compared to the control group (3.03\%) and the patients with $\mathrm{C} \mathrm{BA}(8.5 \%), \mathrm{P}<0.05$. Supraventricular extrasystoles were detected significantly more often in the children with UC BA $(29.0 \%)$ compared to those with C BA $(8.5 \%, \mathrm{P}<0.01)$. In the children with UC BA serum $\mathrm{K}^{+}$was significantly lower compared to the control group, the children with $C B A$ and $P C B A(P<0.001)$. In the children with well controlled BA serum $\mathrm{K}^{+}$ level was also significantly decreased compared to the control group and those with $C B A(P<0.01)$. The analysis of the blood serum $\mathrm{K}^{+}$level to that in erythrocytes ratio showed that $32.2 \%$ of children with UC BA and $13.3 \%$ of those with $P C B A(P<0.05)$ had hypokalemia. Hypokalihistia was found in $18.5 \%$ of the children with UC BA and $10.0 \%$ of those with PC BA $(P<0.05)$. Total serum LDH level was found to be significantly increased in the children with UC BA compared to the control group, children with $C$ $B A(P<0.001)$ and PC BA $(P<0.01)$. Thus, in the children with UC BA total $C P K$ was significantly higher compared to the control group, the children with $C B A(P<0.001)$ and $P C B A(P<0.01)$.

Conclusions. Patients with uncontrolled bronchial asthma commonly have functional cardiovascular disorders, decreased $\mathrm{K}^{+}$level in blood serum and erythrocytes as well as increase in total $\mathrm{CPK}$, isoenzyme CPK-MB, total lactate dehydrogenase and lactate dehydrogenase isoenzyme 1.
Киючові слова: бронхіальна астма, серцево-судинна система, Аіти.

Запорізький медичний

журнал. - 2018. -

T. 20, № 5(110).

C. $646-650$

\section{Структурно-функціональні зміни серцево-судинної системи в дітей, які хворі на бронхіальну астму}

\section{О. В. Герасимова, Т. А. Процюк, А. О. Процюк, А. А. Коцур}

Мета роботи - вивчити стан серцево-судинної системи в дітей шкільного віку залежно від рівня контролю бронхіальної астми (БА).

Матеріали та методи. У дослідження включили 189 дітей віком 6-17 років, які хворі на БА, і 30 умовно здорових осіб, котрі ввійшли в контрольну групу, зіставну за віком і статтю учасників. Крім загальноклінічного обстеження здійснили оцінювання електрокардіограм (ЕКГ) і рівня маркерів ушкодження міокарда (загальної креатинфоссфокінази та лактатдегідрогенази (ЛДГ), ізоферментів КФК-МВ і ЛДГ $)$ ) та електролітів крові (Кㅜ у сироватці крові, еритроцитах).

Результати. Синусову тахікардію виявляли вірогідно частіше в дітей із НКБА порівняно з дітьми з КБА (30,6 \% проти 8,05\%, p < 0,01) і групою контролю $(30,6 \%$ проти 6,06 \% (p < 0,001) відповідно. Вірогідно частіше серед дітей із НК БА спостерігали брадіаритмію порівняно з групою контролю (19,3 \% проти 3,03 \%, p < 0,05) і дітьми з К БА $(19,3$ \% проти 8,5 \%, p < 0,05). Надшлуночкові екстрасистоли вірогідно частіше виявляли в дітей із НК БА порівняно з дітьми з К БА (29,0\% проти 8,5\%, $\mathrm{p}<0,01)$. Рівень $\mathrm{K}^{+}$у сироватці крові в дітей із НК БА виявився вірогідно нижчим порівняно з дітьми контрольної групи, дітьми з К БА і ЧК БА ( $p<0,001)$. Показники рівня $\mathrm{K}^{+}$у сироватці крові були вірогідно нижчими в дітей із ХК БА порівняно 3 дітьми з К БА та з контрольної групи ( $p<0,01)$. Аналіз рівня $\mathrm{K}^{+}$у співвідношенні в сироватці крові та еритроцитах показав, що у $32,2 \%$ дітей із НК БА та 13,3 \% дітей із ЧК БА ( $<<0,05)$ наявна гіпокаліємія. Гіпокалігістію виявили у $18,5 \%$ дітей із НК БА та 10,0 \% дітей із ЧК БА ( $<$ < 0,05). Встановили вірогідне збільшення рівня загальної ЛДГ у сироватці крові в дітей із НК БА, на відміну від дітей контрольної групи, К БА $(p<0,001)$ і ЧК БА $(p<0,01)$. У дітей із НК БА рівень загальної КФК виявився вірогідно вищим порівняно з дітьми контрольної групи, дітьми з К БА $(p<0,001)$ і ЧК БА $(p<0,01)$.

Висновки. Хворим із НК БА властиві порушення функціонального стану серцево-судинної системи, зменшення рівня калію в сироватці крові, еритроцитах і підвищення рівня загальної КФК, ізофрерменту КФК-МВ, загальної ЛДГ та ізоферменту ЛДГ .

\section{Ключевые слова:} бронхиальная астма, сердечнососудистая система, Аети.

\section{Структурно-функциональные изменения сердечно-сосудистой системы у детей с бронхиальной астмой}

\section{Е. В. Герасимова, Т. А. Процюк, ^. А. Процюк, А. А. Коцур}

Цель работы - изучить состояние сердечно-сосудистой системы у детей школьного возраста в зависимости от уровня контроля бронхиальной астмы. 
Материалы и методы. Обследованы 189 детей в возрасте 6-17 лет, больных БА, и 30 условно здоровых лиц, которые вошли в контрольную группу, сопоставимую по полу и возрасту участников. Помимо общеклинического обследования проведена оценка ЭКГ, уровня маркеров повреждения миокарда (общей креатинфосфокиназы и лактатдегидрогеназы, изоферментов КФК-МВ и ЛДГ $)$, электролитов крови (К+ в сыворотке крови, эритроцитах).

Результаты. Синусовая тахикардия, обнаруженная у 30,6 \% детей с НК БА, отмечена достоверно чаще в сравнении с детьми с К БА - 8,05\% ( $<<0,01)$ и группой контроля - 6,06 \% ( $<0,001)$. Брадиаритмия достоверно чаще установлена у детей с НК БА (19,3 \%) в сравнении с детьми с К БА (8,5 \%) и группой контроля - 3,03\% $(p<0,05)$. Наджелудочковые экстрасистолы достоверно чаще обнаруживали у детей с НК БА (29,0 \%) в сравнении с детьми с К БА $(8,5 \%$, p $<0,01)$. У детей с НК БА уровень $\mathrm{K}^{+}$в сыворотке крови был достоверно ниже по сравнению с детьми контрольной группы, детьми с К БА и ЧКБА ( $p<0,001)$. У детей с ХК БА уровень $\mathrm{K}^{+}$в сыворотке крови также был достоверно снижен по сравнению с детьми контрольной группы и К БА $(p<0,01)$. Анализ уровня $\mathrm{K}^{+}$в сыворотке крови и эритроцитах в соотношении показал, что у $32,2 \%$ детей с НК БА и 13,3 \% детей с ЧК БА ( $p<0,05)$ наблюдали гипокалиемию. Гипокалигистия обнаружена у $18,5 \%$ детей с НК БА и 10,0 \% детей с ЧК БА ( $p<0,05)$. Установлено достоверное увеличение уровня общей ЛДГ в сыворотке крови у детей с НКБА в отличие от детей контрольной группы, с КБА $(p<0,001)$ и ЧКБА $(p<0,01)$. У детей с НК БА уровень общей КФК достоверно выше по сравнению с детьми контрольной группы, детьми с К БА $(p<0,001)$ и ЧК БА $(p<0,01)$.

Выводы. Больным с НК БА присущи нарушения функционального состояния сердечно-сосудистой системы, снижение уровня калия в сыворотке крови и эритроцитах, повышение уровня общей КФК, изофермента КФК-МВ, общей лактатдегидрогеназы и изофермента ЛДГ.

Bronchial asthma (BA) in childhood is an important medical and social problem [1,2]. Study of clinical manifestations and pathogenesis of bronchial asthma (BA) complicated by comorbid diseases, foci of chronic infection as well as the differential and diagnostic criteria of its variants development taking into account clinical, allergologic, genetic and immunologic aspects are the urgent problems in modern medicine. [3]. Due to changes in hemodynamics and the risk of possible complications such as arrhythmias and conduction dosorders, pulmonary hypertension, cardiovascular system in bronchial asthma assessment is essential. Severe asthma, emphysema, chronic hypoxia and hypoxemia that arise in bronchial asthma, pronounced neurovegetative imbalance, persistent increase in pulmonary artery pressure, accompanied by significant metabolic disturbances in the myocardium, lead to the degenerative changes and cor pulmonale development. Cardiovascular system (CVS) status in BA is influenced by chronic inflammation, hypoxia, metabolic hemostasis disturbances and drugs cardiotoxicity. CVS changes in children with BA are directly influenced by the disease duration and severity. Unfortunately, as the character of CVS-associated complaints is nonspecific, cardiac pathology in this category of children is not detected early. Late diagnostics of the cardiovascular system complications in children with asthma, inadequate assessment of prognosis and cardiotropic therapy absence underlie the high morbidity and mortality in adulthood.

\section{Objective}

To study the cardiovascular system status in schoolchildren depending on the level of bronchial asthma control.

\section{Materials and methods}

189 children with persistent BA aged 6-17 years, who underwent in-patient treatment at the Pulmonology Department of Vinnytsia Regional Clinical Hospital, and 30 apparently healthy children of the control group were comprehensively examined. Diagnosis was confirmed on the basis of the "Protocol for Diagnosis and Treatment of Bronchial Asthma in Children" criteria, approved by the Order of the Ministry of Health of Ukraine of October 8, 2013. The children were divided into groups according to BA con- trol level, determined by asthma control test (ACT-test). The main group consisted of 124 patients $(65.6 \%)$ with uncontrolled course of the disease (UC BA) and the comparison group consisted of 30 patients (15.9\%) with partially controlled BA (PC BA) and 35 patients (18.5\%) with controlled $B A(C B A)$. The complaints associated with cardiovascular system, changes in electrocardiogram (ECG), markers of myocardial damage (total creatine phosphokinase (CPK) and lactic dehydrogenase (LDH), isoenzymes CPK-MB and $\left.\mathrm{LDH}_{1}\right)$ as well as blood electrolytes $\left(\mathrm{K}^{+}\right.$in serum and erythrocytes) were studied to assess the cardiovascular system status in children with various levels of BA control.

The unified flame photometry method with fluid analyzer FFA-1 (Ukraine) was used to determine the erythrocyte potassium level. Total CPK level was estimated by UV-test with CPK measurement kit and control serums SERODOS (Human Diagnostics, Germany). CPK-MB level was determined by M-subunit immunoinhibition and UV-kinetic method with the kit for CPK-MB measurement and control serums with human CPK-MB (Human Diagnostics, Germany). Total $\mathrm{LDH}_{1}$ level was calculated by modified colorimetric method using an assay kit for colorimetric evaluation of total LDH and control serums SERODOS (Human Diagnostics, Germany). Humalyzer 2000 analyzer (Human Diagnostics, Germany) was used to determine CPK, CPK-MB and LDH levels. Serum $\mathrm{LDH}_{1}$ level was estimated by UV-method with the kit for isoenzyme $\mathrm{LDH}_{1}$ activity determination ("Filicit-Diagnostics", Ukraine), with photoelectric photometer CPK-3-01 (Zagorsk Factory of Optical Mechanics, Russia).

Statistical data processing was done with Statistical package for Windows v. 8.0 using parametric and nonparametric methods. Digital information of all clinical investigations was processed by variance statistical method calculating the mean value $(M)$ and its error $(m)$. The significance of difference between two means was calculated by Student's t-test ( $\mathrm{t}$ ), between two relative values - by Fisher angular transformation method (f). For all specific data the median (Me), lower and upper quartiles [LQ 25-UQ 75] were identified. Two unrelated groups were compared by Mann-Whitney U-test. Two related samples were compared by Wilcoxon T-test. All $P$ values $<0.05$ were considered to be statistically significant.
Запорожский медицинский журнал. - 2018. T. 20, № 5(110). C. 646-650 


\section{Results and discussion}

The detailed analysis of complaints associated with cardiovascular system in children with various levels of BA control demonstrated that clinical symptom such as palpitation was observed in $61.2 \%$ of children with uncontrolled BA, and it occurred significantly more often compared with the control group children $-6.06 \%(P<0.001)$, with controlled BA-11.4 \% (P<0.001) and partially C BA - 33.3\% $(P<0.01)$; its onset was significantly different in children with PC BA compared with the control group $(P<0.05)$. The intermittent palpitations occurred significantly more often in the children with UC BA (38.7 \%) compared with the C BA patients $-8.5 \%(P<0.001), P C B A-20.0 \%(P<0.05)$ and the control group $-3.03 \%(P<0,001)$. It should be noted that such symptoms as pain in the cardiac region, loss of consciousness occurred more often in the children with UC BA. But there was no significant difference in those symptoms in comparison groups $(P>0.05)$, while dizziness was observed significantly more often in the children with UC BA compared to the control group $(P<0.001)$.

The headache was noted significantly more often in the children with UC BA- $64.4 \%$ compared to the children with PC BA-33.3 \% ( $P<0.01), C B A-14.2 \%(P<0.001)$ and the control group $-6.06 \%(P<0.001)$. Besides, symptom such as weakness was found in $66.6 \%$ of children with UC BA, and it occurred significantly more frequent in that category of patients compared to those in the control group $6.06 \%(P<0.001)$, with $C B A-14.2 \%(P<0.001)$ and $P C$ $\mathrm{BA}-36.6 \%(\mathrm{P}<0.001)$; at the same time the headache was significantly more severe in the children with $\mathrm{PC} B A$ compared to those in the control group $(P<0.05)$. It should be emphasized that clinical symptoms of cardiovascular disorders in the examined patients were insufficiently informative and specific and did not reflect all specific features and the extent of morphologic and functional changes in CVS, requiring more comprehensive, profound instrumental and laboratory investigations.

ECG indices in examined patients differed depending on the level of BA control. Sinus rhythm in $92.7 \%$ of children with UC BA did not significantly differ from the children of comparison groups $(P>0.05)$. Only in $7.2 \%$ of children with UC BA and $6.6 \%$ with PC BA wandering atrial pacemaker was detected. Rhythm disturbances in the form of sinus tachycardia were detected in $30.6 \%$ of children with UC BA and it was significantly more frequent compared to the children with $C B A-8.05 \%(P<0.01)$ and the control group $6.06 \%(P<0.001)$. Bradycardia occurred significantly more often in those with UC BA $(19.3 \%)$ compared to the control group $(3.03 \%)$ and the patients with $\mathrm{CBA}(8.5 \%), \mathrm{P}<0.05$, as a result of cardiac rhythm neurovegetative regulation disturbances. Supraventricular extrasystoles were detected significantly more often in the children with UC BA (29.0\%) compared to those with C BA $(8.5 \%, \mathrm{P}<0.01)$. Their occurrence could be explained by the increased level of endogenous catecholamines resulting in electric myocardial instability, and the beta-adrenergic receptors stimulation led to local increase in adrenaline concentration in the sinus node. Isolated monotypic ventricular premature beats were registered in $12.0 \%$ of the children with UC BA, $10.0 \%$ - with PC BA, $8.5 \%$ - with C BA, and there was no significant difference in their number between the groups $(P>0.05)$. Incomplete right bundle branch block was regi- stered in $25.8 \%$ of the children with UC BA and $23.3 \%$ of patients with PC BA. This ECG abnormality was observed with similar frequency $(18.1 \%, P>0.05)$ in healthy children and in those with $\mathrm{CBA}$, which had been confirmed earlier by other investigators. Early repolarization syndrome was not specific for the examined patients, but it was registered in $8.06 \%$ of the children with UC BA $(P>0.05)$ compared with the control group.

Whereas according to Z. G. Davletgildeyeva et al., [4] ECG examination of children with asthma showed sinus tachycardia $(41.8 \%)$, bradycardia $(32.7 \%)$, arrhythmia $(21.8 \%)$, atrial extrasystoles $(5.4 \%)$, single ventricular extrasystoles (1.8\%), wandering atrial pacemaker (3.6\%).

The following changes in ECG findings were found: partial premature excitation syndrome occurred in $7.2 \%$ of the children with UC BA, $6.6 \%$ - with PC BA, $5.7 \%$ - with $\mathrm{CBA}$ and in $3.03 \%$ of the control group children. Short $\mathrm{PQ}$ interval syndrome with normal QRS complexes or attacks of paroxysmal tachycardia were detected in $13.0 \%$ of the children with UC BA, $10.0 \%$ - with PC BA, $5.7 \%$ - with C BA and in $3.03 \%$ of the control group children. No significant difference between the comparison groups of children with premature excitation syndrome and short $P Q$ interval syndrome was found $(P>0.05)$. QT interval elongation was registered in the children with UC BA and PC BA as well, it being the predictor of fatal rhythm disturbances which in its turn could lead to sudden death. QT interval elongation occurred predominantly in the children with UC BA- $27.4 \%$, compared to those with PC BA - $(6.6 \%, \mathrm{P}<0.05)$. QT interval elongation was not observed in the children with $\mathrm{C}$ $\mathrm{BA}$ and in the control group.

The following heart rhythm disorders was detected in $47.0 \%$ of children with BA by Collins $S$ et al. [5]: supraventricular extrasystoles - in $30 \%$ of cases, wandering atrial pacemaker - in $18.3 \%$, first-degree AV-block - in $5.8 \%$ of the children with BA. QT interval elongation was registered in $25.9 \%$ of children with BA. It was noted that heart rhythm disorders and QT interval elongation were mostly manifested with an increase in severity and duration of the underlying disease.

Decreased repolarization processes were detected in $33.3 \%$ of children with UC BA, $16.6 \%$ - with PC BA, $2.8 \%$ - with C BA, while no such changes were found in the control group. Impaired repolarization processes were significantly more frequent in the children with UC BA than in those with PC BA and C BA $(P<0.05)$. Metabolic disturbances and ECG signs of subendocardial ischemia indicated the development of metabolic and hypoxic cardiomyopathy in BA patients, requiring appropriate therapeutic activities in the underlying disease treatment as well as cardiovascular system maintenance. Morphometric analysis of cardiac indices in the children with BA showed that sizes of the left heart were within normal range, and no significant differences were found between the groups without regard to level of BA control. Because of technical difficulty for the right heart morphofunctional parameters calculation due to complicated geometry and anatomic features of the right ventricle as well as the presence of pulmonary emphysema, we used the method of tricuspid annular plane systolic excursion (TAPSE) to assess the right ventricular systolic function. The TAPSE score was $2.12 \pm 0.01 \mathrm{~cm}$ in the children with UC BA, being significantly higher compared 
Table 1. Myocardial damage markers level - total creatine phosphokinase and isoenzymes CPK-MB depending on the level of bronchial asthma control

\begin{tabular}{|l|l|l|l|l|}
\hline Laboratory data & $\begin{array}{l}\text { Control group } \\
(\mathbf{n}=33)\end{array}$ & $\begin{array}{l}\text { Children with C BA } \\
(\mathbf{n}=35)\end{array}$ & $\begin{array}{l}\text { Children with PC BA } \\
(\mathbf{n}=30)\end{array}$ & $\begin{array}{l}\text { Children with UC BA } \\
(\mathbf{n}=124)\end{array}$ \\
\hline Total CPK,U/I Me[LQ;UQ] & $152[140.2-173.0]$ & $155.1[140.0-175.0]$ & $225.0[180.0-289.3]^{* \#}$ & $295.1[290.1-302.2] \S^{\wedge \ell}$ \\
\hline CPK-MB, U/I Me[LQ;UQ] & $19.6[16.2-22.3]$ & $20.0[18.4-24.4]$ & $37.5[25.0-52.2]^{*} \#$ & $61.2[46.0-69.5] \S^{\wedge} \ell$ \\
\hline
\end{tabular}

*: significance of difference of PC BA indices compared with the control group, $\mathrm{P}<0.01$; §: significance of difference of UC BA indices compared with the control group, $\mathrm{P}<0.001$; $\#$ : significance of difference of $P C B A$ indices compared with $C B A, P<0.01 ; \wedge$ : significance of difference of $U C B A$ indices compared with $C B A, P<0.001 ; \ell$ : significance of difference of UC BA indices compared with PC BA, $P<0.01$.

with the control group $(2.40 \pm 0.01, P<0.001)$, the patients with $\mathrm{CBA}(2.38 \pm 0.01, \mathrm{P}<0.01)$ and $\mathrm{PC} B A(2.36 \pm 0.08$, $P<0.01$ ), indicating the tendency to right ventricular systolic dysfunction in the UC BA group. More detailed study of TAPSE score in the children with UC BA found that it was $2.0 \mathrm{~cm}$ in $8.13 \%$ of the patients and corresponded to $50 \%$ of right ventricular ejection fraction according to the scaled table, suggesting the right ventricular systolic function decrease.

Fedortsiv O. Ye., Voloshyn S. B. [6] have registered electrocardiogram abnormalities among the patients with bronchial asthma exacerbation with high frequency $(96.1 \%)$, changes mainly related to hypoxia $(80.4 \%)$, conduction disorders (39.2\%), the signs of right heart overload $(33.3 \%)$. So, there is a dependence between the degree of respiratory function disturbance and electrocardiographic changes frequency during exacerbation and associated with the asthma severity increasing.

Because the indices of cardiac systolic function, specifically cardiac output and cardiac index are influenced by heart rate level, we analyzed it in the children with BA depending on the level of BA control and found the heart rate level in the children with UC BA was $105.7 \pm 1.3 \mathrm{~b} / \mathrm{min}$, with PC BA $-93.8 \pm 2.7 \mathrm{~b} / \mathrm{min}$ and it was significantly higher compared to the control group $-85.2 \pm 1.8 \mathrm{~b} / \mathrm{min}$ and $\mathrm{C}$ $\mathrm{BA}-86.4 \pm 1.8 \mathrm{~b} / \mathrm{min}(\mathrm{P}<0.001)$. Significant difference between those indices was observed in the children with UC BA and PC BA as well $(P<0.01)$. Thus, the lower the level of $B A$ control is, the higher the heart rate. As to the systolic function of the heart (stroke volume, systolic output index, ejection fraction, fractional shortening), it was typical within the expected range for age, and there were no significant differences in those parameters between the comparison groups, while cardiac output, due to heart rate increasing, was significantly higher in the children with UC BA $-7.2 \pm 0.7 \mathrm{I} / \mathrm{min}$ compared with the control group $3.1 \pm 0.1 \mathrm{l} / \mathrm{min}, \mathrm{C} \mathrm{BA}-3.5 \pm 0.1 \mathrm{l} / \mathrm{min}$ and PC BA $-5.3 \pm$ $0.2 \mathrm{l} / \mathrm{min}(\mathrm{P}<0.001)$.

In the children with UC BA cardiac index was $3.6 \pm 0.06$ $\mathrm{l} / \mathrm{min} / \mathrm{m}^{2}$ and it was significantly higher compared to those with C BA - $3.2 \pm 0.04 \mathrm{l} / \mathrm{min} / \mathrm{m}^{2}$ and the control group $3.0 \pm 0.08 \mathrm{l} / \mathrm{min} / \mathrm{m}^{2}(P<0.001)$, while no significant difference in that index among the children with UC BA and PC $B A$ was found $(P>0.05)$. In the children with PC BA cardiac index was significantly higher compared with the control group $(P<0.05)$, and it was similar to that in $C$ BA children $(P>0.05)$.

In BA the impact of pathogenetic factors is known to cause metabolic derangements in the myocardium. V.A. Kondratiev, A. V. Reznik [7] have found in the majority of such cases (in girls $-73.9 \%$, in boys $-53.8 \%$ ) decrease in contractile myocardium function due to metabolic disorders in the form of ventricular complex repolarization changes on electrocardiogram. The earliest manifestations of substantial metabolic and morphologic changes in the myocardium are increase in myocardial damage markers - creatine phosphokinase (CPK) and CPK-MB isoenzyme and lactic dehydrogenase $1\left(\mathrm{LDH}_{1}\right)$ as well as decrease in serum and cellular $\mathrm{K}^{+}$levels. The results of myocardial damage markers study in different levels of BA control are presented in Table 1.

Thus, in the children with UC BA total CPK level was 295.1 [290.1-302.2] U/l, and it was significantly higher compared with the control group - 152 [140.2-173.0] U/l, the children with $C B A-155.1[140.0-175.0] \mathrm{U} / \mathrm{P}(\mathrm{P}<0.001)$ and PC BA-225.0 [180.0-289.3] U/I $(P<0.01)$. In the children with $\mathrm{PC}$ BA total serum CPK level was significantly higher compared with the control group and the children with $C B A(P<0.01)$. There was no significant difference in that index between the children with $\mathrm{CBA}$ and the control group. Having analyzed CPK-MB level, a similar tendency was found: its significant increase in the children with UC BA42.5 [32.0-49.0] U/l, compared with the control group - 19.6 [16.2-22.3] U/l, with C BA-20.0 [18.4-24.4] U/I $(P<0.001)$ and PC BA-37.5 [25.0-52.2] U/I (P<0.01). CPK-MB level in the children with $\mathrm{PC} B A$ was also significantly increased compared with the control group and with $C B A(P<0.01)$. No significant difference in that index between the children with $\mathrm{C} B A$ and the control group was found.

Total serum LDH level was found to be significantly increased in the children with UC BA-406.2 [260.2-496.2] U/I compared with the control group - 260.1 [240.2-293.0] U/l, children with $\mathrm{C} \mathrm{BA}-262.3$ [242.1-306.2] U/I $(\mathrm{P}<0.001)$ and $P C B A-270.2$ [246.0-316.2] U/I $(P<0.01)$. No other difference within the comparison group was found $(P>0.05)$. Isoenzyme $\mathrm{LDH}_{1}$ level was found to be significantly increased in the children with UC BA-42.5 [32.0-49.0] \% compared with the control group - $18.0[15.0-20.0](P<0.01) \%$, children with C BA-19.0 [16.0-23.0] $(\mathrm{P}<0.01) \%$ and $\mathrm{PC}$ $B A-23.5[18.0-28.0] \%(P<0.05)$. No other difference within the comparison group was found $(P>0.05)$. Having calculated isoenzyme $\mathrm{LDH}_{1}$ level as percentage of total serum LDH in the children with BA depending on the level of control, it was found to be increased twofold in the children with UC BA compared to those of the control group and C $\mathrm{BA}(\mathrm{P}<0.001)$, and 1.8 times compared to those with $\mathrm{PC}$ $\mathrm{BA}(\mathrm{P}<0.05)$.

There are a number of reasons in BA for significant decrease in serum potassium level, among them: hypoxia, prolonged disease course, irregular intake of short acting $\beta_{2}$-agonists, unwarranted increase in glucocorticoid doses, which could possibly lead to negative effects associated with potassium metabolism. Decreased serum potassium level leads to the development of arrhythmias, decreased oxygen supply to the brain cells, decreased blood pressure, increased fatigue and low physical endurance [8]. Because of 
this our aim was to study potassium level in blood serum and erythrocytes and to determine the level of myocardial damage markers in children depending on the level of BA control.

In the children with UC BA serum $\mathrm{K}^{+}$level was found to be $3.3[3.0-4.0] \mathrm{mmol} / \mathrm{l}$ and it was significantly lower compared with the control group - $4.3[3.8-4.7] \mathrm{mmol} / /$, the children with $C B A-4.2$ [3.8-4.5] $\mathrm{mmol} / \mathrm{l}$ and $\mathrm{PC}$ $\mathrm{BA}-3.7[3.2-4.2] \mathrm{mmol} / \mathrm{I}(\mathrm{P}<0.001)$. In the children with well controlled $\mathrm{BA}$ serum $\mathrm{K}^{+}$level was also significantly decreased compared with the control group and $C B A$ $(P<0.01)$. No significant difference in this index between the children with $\mathrm{C} B \mathrm{BA}$ and those of the control group was revealed $(P>0.05)$. The analysis of erythrocyte $K^{+}$ level demonstrated that it was 76.0 [60.0-82.0] mmol/l in the children with UC BA, that was significantly lower compared with the control group - 83.3 [79.0-92.0] mmol//, the children with $C$ BA - 82.0 [78.0-92.0] $\mathrm{mmol} / \mathrm{l}$ and $\mathrm{PC}$ $\mathrm{BA}-80.0[62.0-84.0] \mathrm{mmol} / \mathrm{l}(\mathrm{P}<0.001)$. When comparing the erythrocyte $\mathrm{K}^{+}$level in the children with $\mathrm{C} B A, \mathrm{PC} B A$ and the control group, no significant difference was found $(P>0.05)$. The analysis of the $\mathrm{K}^{+}$level in blood serum to that in erythrocytes ratio showed that $32.2 \%$ of children with UC BA and $13.3 \%$ of those with PC BA $(P<0.05)$ had hypokalemia. Hypokalihistia was found in $18.5 \%$ of the children with UC BA and $10.0 \%$ of those with PC BA $(P<0.05)$. Simultaneous decrease in blood serum and erythrocyte $\mathrm{K}^{+}$level was observed in $17.7 \%$ of children with UC BA and $6.6 \%$ of those with PC BA. Conversely, hypokalemia, hypokalihistia and simultaneous decrease in blood serum and erythrocyte $\mathrm{K}^{+}$level were not revealed in the children with $\mathrm{C} B A$ and in the control group.

\section{Conclusions}

Patients with uncontrolled BA commonly had the following functional cardiovascular disorders: sinus tachycardia, sinus bradycardia, supraventricular arrhythmia, QT interval elongation, increased cardiac output and cardiac index, decreased tricuspid annular plane systolic excursion. Decreased $\mathrm{K}^{+}$level in blood serum and erythrocytes as well as 1.9 times increase in total CPK level, 3 times isoenzyme CPK-MB, 1.5 times total serum LDH and 2.3 times $\mathrm{LDH}_{1}$ were observed.

The perspective of further scientific research in this direction is to study the best ways of pharmacological therapy and rehabilitation in patients with BA.

Conflicts of Interest: authors have no conflict of interest to declare. Конфмікт інтересів: віАсутній.

Information about authors:

Herasymova O. V., MD, PhD, Assistant, Department of Pediatric № 1, National Pirogov Memorial Medical University, Vinnytsia, Ukraine.

Protsiuk T. L., MD, PhD, DSci, Associated Professor, Department of Pediatric №1, National Pirogov Memorial Medical University, Vinnytsia, Ukraine.

Protsiuk L. O., MD, PhD, Assistant, Department of Hygiene and Ecology, National Pirogov Memorial Medical University, Vinnytsia, Ukraine.

Kotsur L. D., MD, PhD, Associated Professor, Department of Propedeutics of Pediatric Diseases with Patient Care, National Pirogov Memorial Medical University, Vinnytsia, Ukraine.
Відомості про авторів:

Герасимова О. В., канд. мед. наук, асистент каф. педіатрії № 1 , Вінницький національний медичний університет імені М. І. Пирогова, Україна.

Процюк Т. А., А-р меА. наук, Аоцент каф. педіатрії № 1 Вінницький національний медичний університет імені М. І. Пирогова, Україна.

Процюк ^. О., канА. меА. наук, асистент каф. загальної гігієни та екології, Вінницький національний медичний університет імені М. І. Пирогова, Україна.

Коцур $\Lambda$. А., канА. меА. наук, Аоцент каф. пропедевтики Аитячих захворювань із доглядом за хворими дітьми, Вінницький національний медичний університет імені М. І. Пирогова, україна.

\section{Сведения об авторах:}

Герасимова Е. В., канА. меА. наук, ассистент каф. педиатрии № 1, Винницкий национальный медицинский университет имени Н. И. Пирогова, Украина.

Процюк Т. ^., А-р меА. наук, Аоцент каф. педиатрии № 1, Винницкий национальный медицинский университет имени Н. И. Пирогова, Украина.

Процюк $\Lambda$. А., канА. меА. наук, ассистент каф. общей гигиены и экологии, Винницкий национальный медицинский университет имени Н. И. Пирогова, Украина.

Коцур $\Lambda$. А., канА. меА. наук, доцент каф. пропедевтики детских заболеваний с уходом за больными детьми, Винницкий национальный медицинский университет имени Н. И. Пирогова, Украина.

НаАійшла Ао редакції / Received: 15.11.2017

Після Аоопрацювання / Revised: 28.12.2017

Прийнято Ао Аруку / Accepted: 15.01.2018

\section{References}

[1] Bousquet, J., Bachert, C., Canonica, G. W., Casale, T. B., Cruz, A. A. Lockey, R. J., et al. (2011) Extended Global Allergy and Asthma European Network, World Allergy Organization and Allergic Rhinitis and its Impact on Asthma Study Group Unmet needs in severe chronic uppe airway disease (SCUAD) J. Allergy Clin. Immunol., 124(3), 428-433. doi: 10.1016/j.jaci.2009.06.027.

[2] Cosmi, L., Santarlasci, V., Angeli R., Maggi, L., Liotta, F., \& Annunziato, F. (2014) Th17 plasticity: pathophysiology and treatment of chronic inflammatory disorders. Current opinion in pharmacology, 17, 12-16. doi: 10.1016/j.coph.2014.06.004.

[3] Protsiuk, T. L., Surkova, N. M. \& Gerasimova, O. V. (2016) Klinikolaboratorni fenotypy bronkhialnoi astmy, uskladnenoi komorbidnoiu patolohiieiu, ta yikh diahnostychne i prohnostychne znachennia u dite [Clinical and laboratory phenotypes of bronchial asthma complicated by comorbid pathology, their diagnostic and prognostic significance in children]. Odeskyi medychnyi zhurnal, 6(158), 75-80. [in Ukrainian].

[4] Davletgildeyeva, Z. G., Choy, S. V., Ramazanova, S. H., \& Zhunusova, A. Z. (2014) Klinicheskie osobennosti i patogeneticheskaya terapiya narushenij serdechno-sosudistoj sistemy u detej s bronkhial'noj astmoj [Linical feature and pathogenetic therapy of cardio-vascular system in children with asthma]. Vestnik Kazahskogo nacional'nogo medicinskogo universiteta, 1, 107-109. [in Russian].

[5] Collins, S., Widger, J., Davis, A., \& Massie, J. (2012) Management of asthma in children with long QT syndrome. Paediatr Respir Rev., 13(2), 100-5. doi: 10.1016/j.prrv.2011.02.003.

[6] Fedortsiv, O. Ye., \& Voloshyn, S. B. (2014). Otsinka funktsionalnoho stanu sertsevo-sudynnoi systemy u ditei iz bronkhialnoiu astmoiu [The evaluation of the cardiovascular system functional state among children with asthma]. Perynatolohiia i pediatriia, 2, 113-115. [in Ukrainian].

[7] Kondratiev, V. A., \& Reznik, A. V. (2016) Henderni vidminnosti sertsevo diialnosti u ditei z bronkhialnoiu astmoiu [Gender peculiarities of cardiac performance in children with bronchial asthma]. Medychni perspektyvy, 16, 21(1), 86-90. [in Ukrainian].

[8] Shumna, T. Ye., Nedelska, S. M., \& Datsenko, O. M. (2014). Vzaiemozviazok porushen bronkholehenevoi i sertsevo-sudynnoi systemy u ditei iz bronkhialnoiu astmoiu: bahatohrannist ta nevycherpnist vyvchennia problemy [Correlation between bronchovascular and cardiovascula disorders in children with bronchial asthma: multifacetedness and inexhaustibility of problem study]. Zdorov'e rebenka, 8(59), 8-11. [in Ukrainian]. 